\title{
A Review on Phytopharmacopial Potential of Epilobium angustifolium
}

\author{
Prasad Kadam ${ }^{1 *}$, Manohar Patil ${ }^{2}$, Kavita Yadav ${ }^{1}$
}

\section{Prasad Kadam ${ }^{*}$ \\ Manohar Patil ${ }^{2}$ \\ Kavita Yadav ${ }^{1}$}

'Department of Pharmacognosy, Associate Professor, Marathwada Mitra Mandal's College of Pharmacy, Pune411033, Maharashtra, INDIA.

${ }^{2}$ Department of Pharmacognosy, Principal and Professor of Pharmacognosy, Marathwada Mitra Mandal's College of Pharmacy, Pune-411033, Maharashtra, INDIA.

\section{Correspondence:}

Mr. Prasad Kadam Marathwada Mitra Mandal's College of Pharmacy, Sr. No 4/17, Sector No.34, PCNTDA, off KalewadiPhata Pimpri Road, Thergaon (Kalewadi), Pune-411033, Maharashtra, INDIA.

Phone no: +919850219875.

E-mail:kadamprasadv@gmail.com

History

- Submission Date: 20-03-2018;

- Review completed: 27-04-2018;

- Accepted Date: 30-07-2018

\section{DOI : 10.5530/pj.2018.6.181}

Article Available online

http://www.phcogj.com/v10/i6

\section{Copyright}

(C) 2018 Phcog.Net. This is an openaccess article distributed under the terms of the Creative Commons Attribution 4.0 International license.

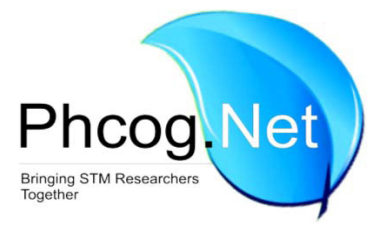

\section{ABSTRACT}

Nature has been a source of medicinal agents for thousands of years, and an impressive number of modern drugs have been isolated from natural sources which are based on their use in traditional medicine. Epilobium angustifolium $L$ is a perennial herbaceous plant that belongs to the Onagraceae family. It exhibits various therapeutic properties like anticancer, antibacterial, anti-inflammatory, antioxidant, and anti-aging properties. Epilobium angustifolium L. contains polyphenols and secondary metabolites like oenothein B. Information was collected via Medline, PubMed, and Science Direct. Also some data have been collected from scientific journals, books, and reports. This review gives the current information on the chemical composition, traditional uses, and documented biological activities of Epilobium angustifolium $L$. These studies reveal that Epilobium angustifolium $L$ is a source of medicinally active compounds and have various pharmacological effects. These studies will be helpful to create interest toward Epilobium angustifolium $L$ and may be useful in developing a new direction for further research. Epilobium angustifolium L.is a medicinally important plant belongs to Onagraceae family. Extract from the plant is used in the treatment of many diseases for its anti-tumor, antimicrobial, anti-inflammatory, antioxidant, anti-ulcer and many other properties. The medicinal properties of fireweed have been attributed to its high content in polyphenols and more particularly to the most abundant of its secondary metabolites: Oenothein B.

Key words: Epilobium angustifolium L, Oenothein B Pharmacological effects, Herbaceous, Biological activities.

\section{INTRODUCTION}

Epilobium angustifolium is a remedial plant that belongs to the Onagraceae family, which contains more than 200 different species. It is called "fireweed" in North America, "rosebay willow-herb" in Great Britain and "maitohorsma" in Finland. ${ }^{1}$ Within Epilobium species, E.angustifolium is one of the wellknown medicinal plants which is used worldwide in customary medicine. Extracts obtained from rosebay willow-herb shows a variety of pharmacological effects. ${ }^{2}$ Epilobium taxa has both in vitro and in vivo studies to show many therapeutic properties, including anti-inflammatory, antiandrogenic, antiproliferative, antimicrobial, Antinociceptive, and antioxidanteffects. ${ }^{3}$ Epilobium angustifolium is widely used in non-traditional medicine to treat gastrointestinal disorders, mucous membrane lesions, such as mouth ulcers, wounds healing, skin sores, swelling. ${ }^{4}$ In the last few decades there has been a growing interest in phytochemical composition of various parts of Epilobium plants.Ellagitannins is the major bioactive compounds present in Epilobium plants. Some ellagitannins present in the plant exhibit immune modulatory activity.
The main biologically active component in Epilobium taxa is Oenothein B (a dimeric macrocyclic ella-

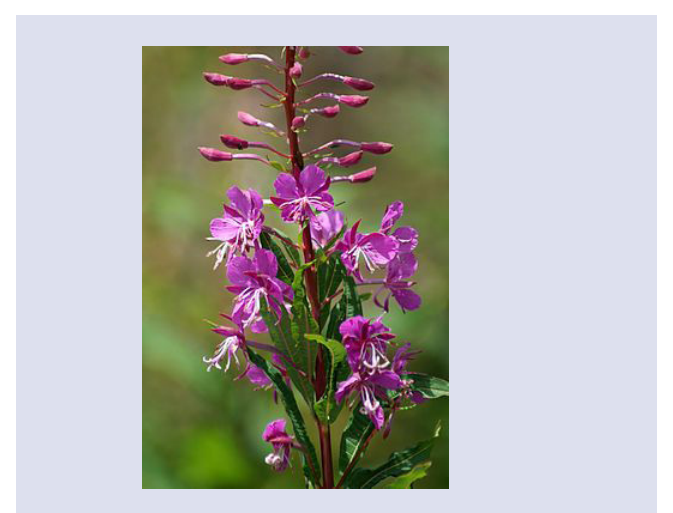

Figure 1: Morphology of Epilobium angustifolium

gitannin) which is present in high concentrations in Epilobiumspecies. Earlier studies on Oenothein B has been revealed significant antioxidant, antitumor, antibacterial, and antiviral activities. ${ }^{3}$ 
The aim of this paper is to give comprehensive review on the chemical composition, traditional uses, and documented biological activities of plant belonging to the Epilobium angustifolium.

\section{Botanical Description}

Herbaceous perennial, forming colonies by extensive system of pseudorhizomes; stem erect, up to $3 \mathrm{~m}$ tall, simple to much branched on top of, glabrous to very pubescent with little upwardly curled trichomes, the inferior parts with exfoliating epidermis; leaf blands linear to broadly elliptic or lanceolate, the abaxial midrib glabrous to very pubescent; inflorescence showy, with from several to 100 flowers; petals pink, 3-17 $\mathrm{mm}$ broad, 7-22 mm long; style usually hairy at base; stigma opening 2-3 days after anthesis. Capsule with up to several hundred comate seeds. ${ }^{5}$

\section{Geographical Distribution}

Epilobium angustifolium is indigenous throughout Canada and most of the United States except for Kansas, Oklahoma, Texas, Missouri, Arkansas, Kentucky, and the southeastern states. In Indiana, Ohio, and North Carolina fireweed is classify as a Endangered species, and in Tennessee it is a Species of Concern. It grows mainly in forest and alpine meadows, in semi-shaded mixed forests and forest edges, and along rivers and streams. This versatile plant can grow almost anywhere. Its main association is as an active colonizer of recently burned areas, behavior that has earned fireweed its name. ${ }^{6,7}$

\section{Active Compounds}

Plant belonging to the Epilobiumgenus area rich source of secondary metabolites, especially polyphenols including flavonoids, phenolic acids and tannins. Apart from polyphenols, some lipophillic compounds such as steroids, triterpenoid and fatty acids have also been isolated and identified from the Epilobiumspecies. ${ }^{8}$

A variety of polyphenols present in Epilobium angustifolium.Three major polyphenol groups has beenidentified in Epilobium angustifolium extracts : flavonoids, phenolic acids, and ellagi tannins. Flavonoids consist offlavonol aglycones (quercetin, kaempferol, and myricetin) and flavonoid glycosides, such as afzelin (kaempferol-3-O-rhamnoside), juglalin (kaempferol-3- O-arabinofuranoside), avicularin (quercetin-3$\mathrm{O}-\alpha$ - arabinofuranoside), hyperoside (quercetin-3-O-galactoside), isoquercetin (quercetin-3-O-glucoside), quercitrin (quercetin-3-O-rhamnoside), and miquelianin (quercetin- 3-O-glucuronide). ${ }^{9}$ Miquelianin is the main flavonoid in Epilobium angustifolium, among the flavonoid glycosides that have been identified in Epilobium species. Whereas myricitrin (myricetin-3-O-rhamnoside) was found to be the main flavonoid in other species. Some of these compounds are active constituents of many remedial plants that are used in conventional medicines for their neuroprotective, anti-inflammatory, antioxidant, anti-proliferative, and other pharmacological properties. Tellimagrandin I-based oligomeric ellagitannins are relatively high-molecular weight polyphenols. ${ }^{10}$

From Epilobium angustifolium extractsseveral other oligomeric tannins have been isolated, including oenotheinn $\mathrm{A}$ (trimer), and tellimagrandin I- based heptameric ellagitannins. Oenothein B is a macro cyclic ellagitannins. Important biological activity shown by Oenothein B which include antioxidant, immunomodulatory, tumor call cytotoxicity, enzyme inhibition, and enzyme induction. ${ }^{2}$

Ellagic acid which is a marker of ellagi tannins occurrence has been detected.Epilobium species including the most popular E angustifolium, E. hirsutum and E. parviflorum. Valoneic acid dilactone has been reported in E. angustifolium. ${ }^{1}$

While other quinic acid esters have only been detected in Epilobium angustifolium using the HPLC-DAD-MS method. ${ }^{11}$ Also Cholesterol, campesterol, stigmasterol, $\beta$-sitosterolandits glycosides and esters have been reported from Epilobium angustifolium. ${ }^{1}$

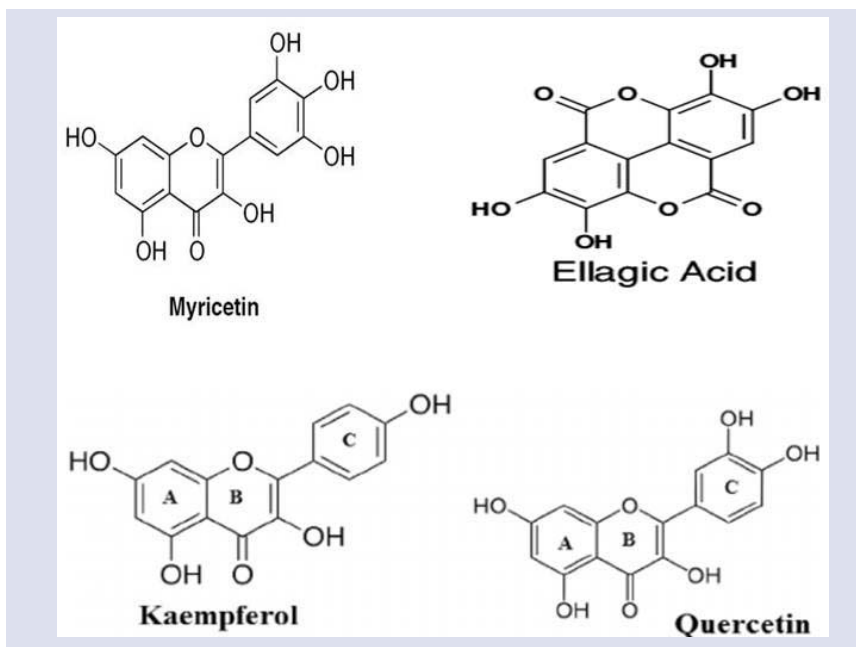

Figure 2: Chemical structures of the important bioactive molecules from Epilobium angustifolium.

\section{Traditional Uses}

Fireweed infusion or tea has been reported for the treatment of migraine headaches, insomnia, anemia, delirium tremens, infections, and colds. Epilobium angustifolium extracts have been helpful in gastric ulcer; duodenal ulcer; gastritis; colitis; various gastrointestinal disorders, such as dysentery and diarrhea; and prostate or urinary problems, such as urethral inflammation, micturition disorders, prostatic adenoma, and benign prostatic hyperplasia (BPH). ${ }^{2}$

Epilobium angustifolium infusions due to its astringent, demulcent and emollient properties, were commended by American herbal list sinthe $19^{\text {th }}$ and early $20^{\text {th }}$ centuryas a very effective agent to treat gastrointestinal diseases such as dysentery and diarrhea of different aetiologiesas well as other bowel and intestinal disorders associated with infection, irritation and inflammation. ${ }^{1}$ Epilobium angustifolium is used to treat whooping cough, hic cough and asthma. ${ }^{12}$ Apoultice made from the leaves of Epilobium angustifolium was applied to burns, beestings, aches and in swelling by Gwich'in people. ${ }^{13}$ The medicinal properties of fireweed have been attributed to its high content in polyphenols and more particularly to the most abundant of its secondary metabolites: oenothein $\mathrm{B}^{14}$. Epilobium angustifolium has also been used topically as a cleansing, soothing, antiseptic,also healing agent to treat minor burns, skin rashes, ulcers, and for treatment of inflammation of the ear, nose, and throat. ${ }^{15}$

\section{Pharmacological Reports}

\section{Antinflammatory activity}

Epilobium angustifolium aqueous extracts have also been reported to have anti-inflammatory properties which reduced carrageenan-induced paw edema. ${ }^{1}$

\section{Analgesic activity}

Fireweed extracts have been reported to exhibit analgesic properties using hot plate and writhing tests. ${ }^{13}$

\section{Antiviral activity}

Epilobium angustifolium extracts administration, prior to influenza virus exposure reduced mortality and increased survival mean time. These effects were even more striking when infection occurred seven days after 
the last administration of the extract, where mortality rate was reduced by $50 \%$ and survival mean time was increased fivefold. ${ }^{3}$

\section{Anti-tumor activity}

Epilobium angustifolium extracts have also been reported to exhibit antitumor properties, including inhibition of human prostate epithelial cell PZ-HPV-7 growth. Likewise, treatment of androgen-sensitive human prostate adenocarcinoma cells LNCaP with Epilobium extracts (20-70 $\mu \mathrm{g} / \mathrm{ml}$ ) resulted in a significant increase in the number of apoptotic cells. Various Epilobium extracts, including extracts from Epilobium angustifolium, caused a similar inhibitory effect on the proliferation of human cancer cell lines and inhibited DNA synthesis in human astrocytoma cells $1321 \mathrm{~N} 1 .{ }^{1}$ In addition, aqueous extract of E. angustifolium demonstrated higher antiproliferative activity than ethanol extracts. ${ }^{16,17}$

\section{Anti-Oxidant activity}

Epilobium angustifolium aqueous extractsare able to scavenge superoxide anion $\left(\mathrm{O}_{2}\right)$ and hydroxyl radicals, as well as inhibit ROS production by stimulated neutrophils. ${ }^{1}$

\section{CONCLUSION}

Epilobium angustifolium is a medicinal plant which is widely used in conventional medicine. Oenothein B is biologically active polyphenols present in this plant extract. The remedial effects of Epilobium angustifolium polyphenol are mediated by multiple mechanisms, including direct killing of cancer cells and microbes, antioxidant activity, metal Chelation and both pro-inflammatory and anti-inflammatory immune modulation. Further, a better understanding of Epilobium angustifolium active molecules and their mechanisms of action is essential for maximizing the therapeutic potential of this interesting plant and ensuring safe use of these compounds as therapeutics.

\section{CONFLICT OF INTEREST}

The authors declare that they have no conflict of interest.

\section{ABBREVIATIONS}

HPLC-DAD-MS: High performance liquid chromatography with diode array detection and Mass spectrometry $\mathbf{B P H}$ : benign prostatic hyperplasia PZ-HPV-7: Human papillomavirus type-7LNCaP: Lymph node carcinoma of the prostate DNA: Deoxyribonucleic Acid ROS: Reactive Oxygen Species

\section{SUMMARY}

- Epilobium angustifolium L.is a medicinally important plant belongs to Onagraceae family.
- Extract from the plant is used in the treatment of many diseases for its antitumor, antimicrobial, anti-inflammatory, antioxidant, antiulcer and many other properties.

- The medicinal properties of fireweed have been attributed to its high content in polyphenols and more particularly to the most abundant of its secondary metabolites: oenothein B.

\section{REFERENCES}

1. Sebastian G, Jakub PP, Monika EC, Anna KK. Phytochemistry, pharmacology and traditional uses of different Epilobium species (Onagraceae): A review. Journal of Ethanopharmacology. 2014;156:316-46.

2. Igor AS, Andrew GR, Liliya NK, Jovanka MV, Mark AJ, Mark TQ. Therapeutic Potential of Polyphenols from Epilobium angustifolium (Fireweed).2016;30(8):1287-97.

3. Schepetkin IA, Kirpotina LN, Jakiw L, Khlebnikov Al, Blaskovich CL, Jutila MA, et al. Immunomodulatory Activity of Oenothein B Isolated from Epilobium angustifolium. The Journal of Immunology. 2009;183(10):6754-66.

4. Halyna O, Oleksandra O, Samuele V, Samuela C, Elisabetta A,Michela C, et al. Epilobium angustifolium L. A medicinal plant with therapeutic properties. The EuroBiotech Journal.2017;1(2):126-31.

5. Theodore M.A New Taxonomy for Epilobium angustifolium L.(Onagraceae).Brittonia. 1966;18(2):167-88.

6. Fleenor R. Plant Guide for Fireweed (Chamerion angustifolium). USDA-Natural Resources Conservation Service, Spokane, WA 99201 http://plants.usda.gov/ plantguide/pdf/pg_chan9.pdf. Accessed: May 15, 2016.

7. Vizgirdas E. Fireweed (Chamerion angustifolium). USDA, Forest Service http:// www.fs.fed.us/wildflowers/plant-of-the-week/chamerion_angustifolium.shtml. Accessed: May 15, 2016.

8. Granica S, Piwowarski JP, Czerwinska ME, Kiss AK. Phytochemistry, pharmacology and traditional uses of different Epilobium species (Onagraceae): A review. J Ethnopharmacol. 2014;156:316-46.

9. Kiss A, Kowalski J, Melzig MF.Compoundsfrom Epilobium angustifolium inhibit thespecific metallopeptidasesACE,NEPandAPN.PlantaMedica.2004:70(10):919-23.

10. Kosalec I, Kopjar N,Kremer D.Antimicrobialactivityofwillowherb (Epilobium angustifolium L.) leavesand flowers.CurrentDrugTargets.2013:14(9):986-91.

11. Stolarczyk M, Naruszewicz M, Kiss AK. Extractsfrom Epilobium sp. herbs induce apoptosiss in human hormone-dependent prostate cancer cells by activating the mitochondrial pathway. Journal of Pharmacy and Pharmacology. 2013;27(12):1842-8

12. Deschauer T. Illustrated Phytotherapy. Thos. Deschauer. Thos. Deschauer Publications, Maywood. 1945.

13. Andre A, Fehr A. Gwich'in Ethonobotany:Plants Used by the Gwich'in for Food, Medicine, ShelterandTools. Gwich'in Social and Culturallnstitute and Aurora Research Institute, Inuvik, 2010.

14. Ducrey B, Marston A, Göhring S, Hartmann RW, Hostettmann K, Inhibition of 5 Alpha-Reductase and Aromatase by the Ellagitannins Oenothein A and Oenothein B from Epilobium Species. Planta Med.1997;63(2):111-4.

15. Vogl S, Picker P, Mihaly-Bison J, et al. Ethnopharmacological in vitro studies on Austria's folkmedicine--an unexplored lore in vitro anti-inflammatory activities of 71 Austrian traditional herbal drugs. J Ethnopharmacology. 2013;149(3):750-71.

16. Tita B, Abdel-Haq H, Vitalone A, Mazzanti G, Saso L. Analgesic properties of Epilobium angustifolium, evaluated by the hot plate test and the writhing test. Farmaco. 2001;56(5-7):341-3.

17. Kiss A, Kowalski J, Melzig MF. Effect of Epilobium angustifolium L. extracts and polyphenols on cell proliferation and neutral end peptidase activity in selected cell lines. 2006;61(1):66-9. 